DOI: 10.11606/issn.2238-3867.v16i1p39-54

sala preta

ppgac

Dossiê Performatividades Originárias

\title{
Corporalidade, musicalidade e aspectos sociais no congado Moçambiqueiro
}

Corporeality, musicality and social aspects in

Mozambican congado

Maria do Socorro Calixto Marques

Tatiane Oliveira Silva

Maria do Socorro Calixto Marques Professora do Curso de Teatro e do PPGAC/

Universidade Federal de Uberlândia

Tatiane Oliveira Silva

Graduada em Teatro

Universidade Federal de Uberlândia

Bolsista pela FAPEMIG em 2012/2013

Professora de teatro, musicista e

pesquisadora

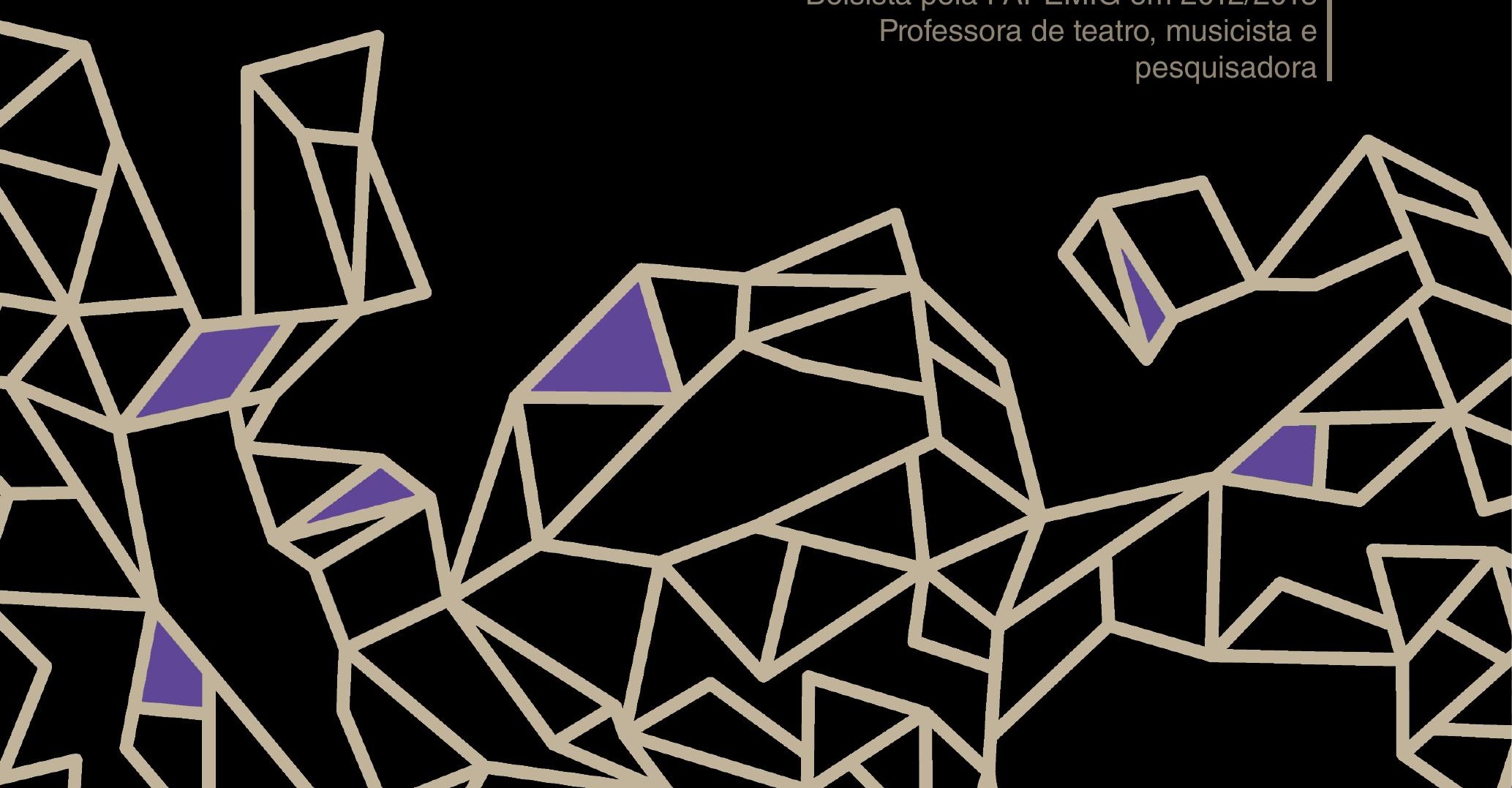




\section{Resumo}

Neste artigo, apresentamos uma breve análise do Congado Uberlandense, festa coletiva que reúne afrodescendentes e honra aos santos da Igreja Católica. A análise se concentra no sincretismo religioso, mas principalmente no que se refere às características musicais, corporais e sociais, tendo por base observações feitas em textos sobre cultura (Canclini), tradição (Arantes) e performance (Schechner).

Palavras-chave: Congado, Cultura popular, Performance.

\section{Abstract}

This article presents a brief analysis of the Congado Movement of Uberlândia, a collective party that gathers African descendents and pays tributes to the saints of the Catholic Church. The analysis focus on religious syncretism, but mainly on the musical, corporal and social features, based on observations of culture (Canclini), tradition (Arantes) and performance (Schechner) literature.

Keywords: Congado, Popular Culture, Performance.

Uberlândia, cidade do Triângulo Mineiro, foi e é ocupada por contingentes de afrodescendentes e ainda apresenta variadas formas de manifestação da cultura afro. A festa do congado é uma delas e se espraia não somente aqui, mas foi nesta cidade que mantivemos contato com essa dança e é sobre ela que falaremos neste artigo. Abordamos especificamente o congado, pois surgido a partir de danças e rituais antes já realizados por antepassados africanos em honra a deuses e ancestrais, a festividade apresenta um movimento rítmico auxiliado por batidas sonoras e exige um estudo mais sutil, pois, aos poucos, converteu-se em um movimento caracterizado pela soma do condicionamento religioso, ao qual negros escravizados eram submetidos pelos jesuítas, logo no início do Brasil Colônia, e suas crenças nos deuses de religiões africanas.

As circunstâncias sociais levaram os cativos a procurar e conquistar lugares para realizar suas cerimônias religiosas e manifestar seu louvor aos an- 
cestrais. Esses traços definiram o critério de escolha para estudo do material que, naturalmente, nasceu da admiração de uma das autoras, pelas tradições de matrizes afrodescendentes e pela riqueza artística do movimento, somada aos estudos sobre cultura e memória da outra.

Dentro desse universo escolhido, optamos por observar o Moçambique de Belém, visto que o terno é um dos mais tradicionais da cidade e por eles fomos bem recebidas. Apesar de se tratar de um movimento com uma causa comum - o louvor - o congado possui em seu interior uma imensa gama de diversidades que se subdividem em diferentes tipos de ternos, entre Moçambiques, Catupés e Congos. Cada um desses ternos se caracteriza por uma batida e indumentária que os distingue. Entre eles há também uma hierarquia que leva o Moçambique a ocupar lugar de destaque em relação aos demais, seguido pelos Catupés, posteriormente os Marinheiros e, finalmente, os outros tipos de Congos.

A diferenciação não se dá somente no campo operacional dos ternos entre si ou a uma simples questão de diferença rítmica. Essa hierarquização, segundo Jeremias Brasileiro (2013), em entrevista, está profundamente calcada na questão da religiosidade católica, inclusive, deve-se, especialmente na região mineira, ao mito do surgimento de Santa Ifigênia, que foi encontrada no fundo das águas, e, posteriormente, o de Nossa Senhora do Rosário, nas ondas do mar. Para contextualizar o leitor, destacamos, a seguir, o trecho retirado da entrevista que nos foi concedida:

Um dos mitos é de que Santa Ifigênia, por ser negra, não era aceita na Igreja junto com São Benedito, porque eram ambos negros. Santa Ifigênia passa a missão pra Nossa Senhora do Rosário cuidar dos negros escravizados, só que Nossa Senhora do Rosário também se recusa a sair do mar para cuidar desses negros. Ocorre então que os grupos, as bandas, bandas de congo, os marinheiros com suas fanfarras, um a um, eles vão à beira da praia cantar para que Nossa Senhora do Rosário venha com eles, mas ela não sai. A partir do momento os grupos de Candongue, que a gente não tem e era anterior ao Moçambique, vão e cantam pra Nossa Senhora do Rosário, e um dos capitães ergue os bastões chamando pra que ela venha. E ela vem, senta-se no bastão que é colocado no tambor, e torna-se um andor, e eles vão levá-la pra igreja. Mas isso tudo acontece porque o Moçambique é o único que canta e não dá as costas pra Nossa 
Senhora do Rosário. Os outros cantam, chamam e dão as costas. Eles chamam puxando-a de fato e por isso ela vem com eles.

Embora tenhamos feito um apanhado geral dos elementos colhidos durante a observação não somente do Moçambique de Belém, mas também do Moçambique Branco da cidade de Araguari e do Moçambique Quilombo dos Palmares em Uberlândia, fora a observação dos inúmeros ternos nos dias de festas na cidade, foram necessárias algumas delimitações, como a seleção de um terno: o Moçambique de Belém.

Durante dois períodos do ano, os membros da tradição congadeira se juntam para organizar duas festas, uma é o "Encontro de Congadeiros, Moçambiques, Marujos e Catupés" e a outra é a "Festa em Louvor a Nossa Senhora do Rosário". As festas se dão no período de meados de maio e no segundo domingo de outubro, respectivamente. Durante as observações, tópicos como a corporalidade rítmica e a religiosidade (sincrética), características próprias do movimento, foram descritas e examinadas.

Concomitantemente ao processo de observação de elementos culturais que poderiam levar ao reconhecimento de certa ancestralidade, fez-se necessária a busca de definições de conceitos como "cultura", "popular", "identidade" e "tradição", a fim de somar as observações a uma base teórica. E, na voz de Canclini (2000, p. 221), encontramos uma noção sobre um dos sentidos de "popular" que vem respaldar nossas observações: "por extensão, é possível pensar que o popular é constituído de processos híbridos e complexos, usando como signos de identificação elementos procedentes de diversas classes e nações."

$\mathrm{O}$ autor mostra como esses conceitos se encontram entre questões maiores, como a da dominação social - cultura popular sendo considerada, quase sempre, como advinda de uma classe dominada ou produzida de forma massiva - e do que é considerado culto ou inculto. Percebe-se, então, que a consideração da ideia de povo como uma força mínima e puramente passiva reflete um ponto de vista deveras infundado.

Uma ideia aqui é reforçada: o congado, assim como muitas outras manifestações culturais (a do Bumba meu boi, por exemplo), surge a partir de uma relação dicotômica "dominador $x$ dominado". E encontramos essa dicotomia registrada no corpo dos brincantes: de fato, o moçambiqueiro comporta-se 
como um guerreiro, com movimentações agressivas e repletas de demonstração de força física e espiritual. Como são muitas as interpretações e os caminhos possíveis a serem trilhados, foi preciso esclarecer a livre associação que fazemos da cultura popular com a tradição, uma vez que essas estão intrinsecamente ligadas, mas não se limitam apenas uma na outra, pelo menos é o farol que seguimos, de acordo com Antonio Augusto Arantes (1980):

\begin{abstract}
Desse ponto de vista, a "cultura popular" surge como uma "outra" cultura que, por contraste ao saber culto dominante, apresenta-se como "totalidade" embora sendo, na verdade, construída através da justaposição de elementos residuais e fragmentários considerados resistentes a um processo "natural" de deterioração. (p. 18-19)
\end{abstract}

Essa justaposição de elementos a que o autor se refere iluminou as observações e a realização de entrevistas, pois, ao observar o movimento congadeiro, assim como em outras formas de manifestação cultural que se mantêm enquanto tradição, constatamos que os processos, ao longo do tempo, passaram por um movimento de "deteriorização", mas, por outro lado, que existem características que permaneceram imutáveis, as quais, do nosso ponto de vista, são partículas que alimentam o movimento que vai se adaptando de acordo com diferentes tempos, pessoas, conduções e condições a que foram submetidos ao longo de seus mais de 300 anos.

Vejamos alguns elementos dessa manifestação cultural que, a despeito do hibridismo e do processo de deteriorização, são persistentes e trazem muito da matriz africana.

Durante o acompanhamento da festa, percebemos que somente o moçambiqueiro fazia o uso da gunga ${ }^{1}$. Esse objeto, além de instrumento percussivo, quando utilizado ganha força espiritual, uma vez que, segundo entrevistas, serve para espantar maus espíritos e forças negativas que queiram se aproximar do brincante. Outro instrumento bastante utilizado por ternos de Moçambique é a patangonga ${ }^{2}$, que, somada aos demais instrumentos, faz com que a chegada de um terno de Moçambique proporcione sensações

1 Gunga: chocalho feito de metal ou cabaça usado nos pés do moçambiqueiro.

2 Patangonga: também conhecida como "patangoma" ou "patangome" é um chocalho de metal de tamanho médio tocado com as mãos. 
semelhantes às de um tremor na superfície do solo. Observando o modo performativo, pode-se dizer que o movimento da patangonga se assemelha ao das peneiras usadas por garimpeiros escravizados na época do ouro. Essa recepção nos leva a perceber as capacidades sensoriais que são acessadas através do movimento, seja devido à dança, à música, à visualidade ou ao seu caráter espiritual.

O congado reveste-se de uma prática que envolve corpo, musicalidade e religião. Consequentemente, a mistura desses elementos exige de seu observador um foco voltado para o campo mais sensorial, pois ritmo e movimentos corporais são constituídos ao longo de uma práxis diária.

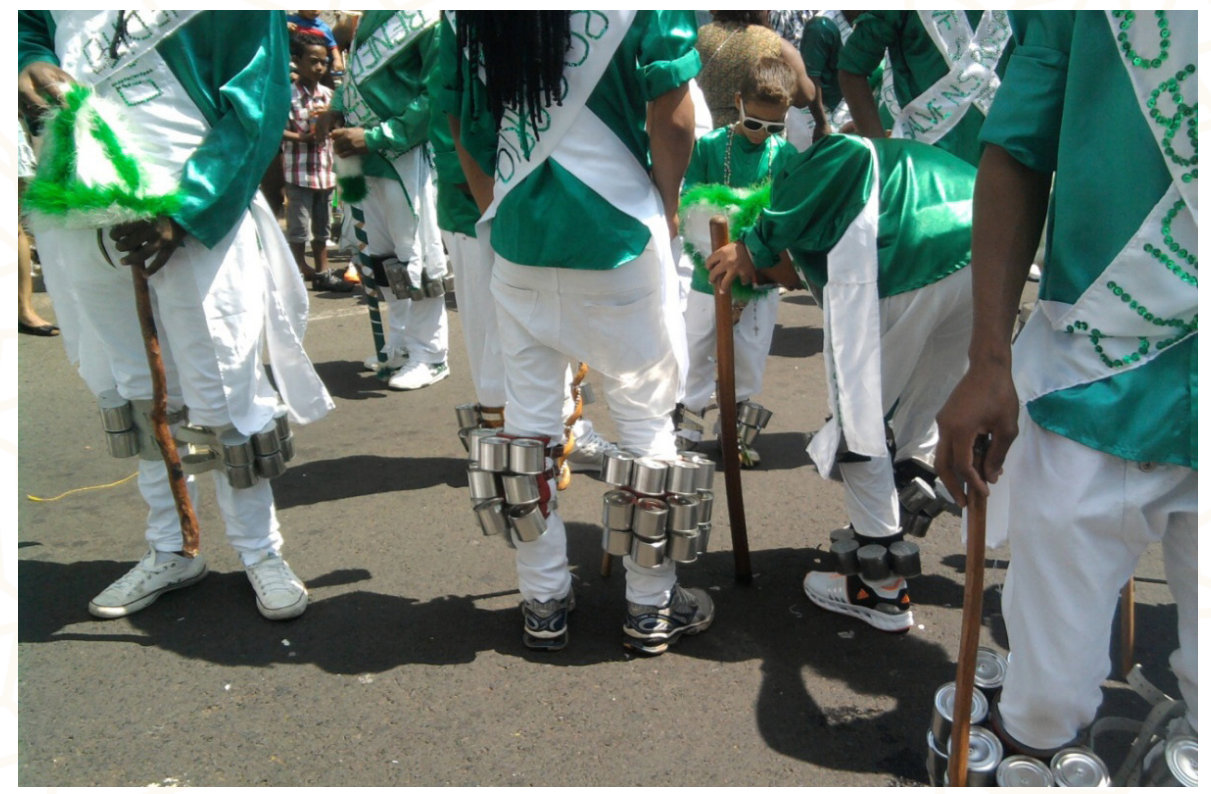

Figura 1 - Dançadores usando a gunga amarrada aos pés. Festa em Louvor a Nossa Senhora do Rosário e São Benedito, 2012. Imagem: Tatiane Oliveira.

Outro objeto utilizado pelos moçambiqueiros é o bastão. Ninguém, além de seu dono, pode tocá-lo ou manuseá-lo; hierarquia que se relaciona ao fato de que, de acordo com a religiosidade, o bastão representa a força do dançador. Enfeitado com patuás, terços e fitas, o bastão passa por um ritual de benção antes de o terno sair à rua. Existem alguns capitães de outros ternos de congo que fazem uso desse elemento, no entanto não são todos os integrantes que podem utilizá-lo devido a sua força e manifestação de poder. 


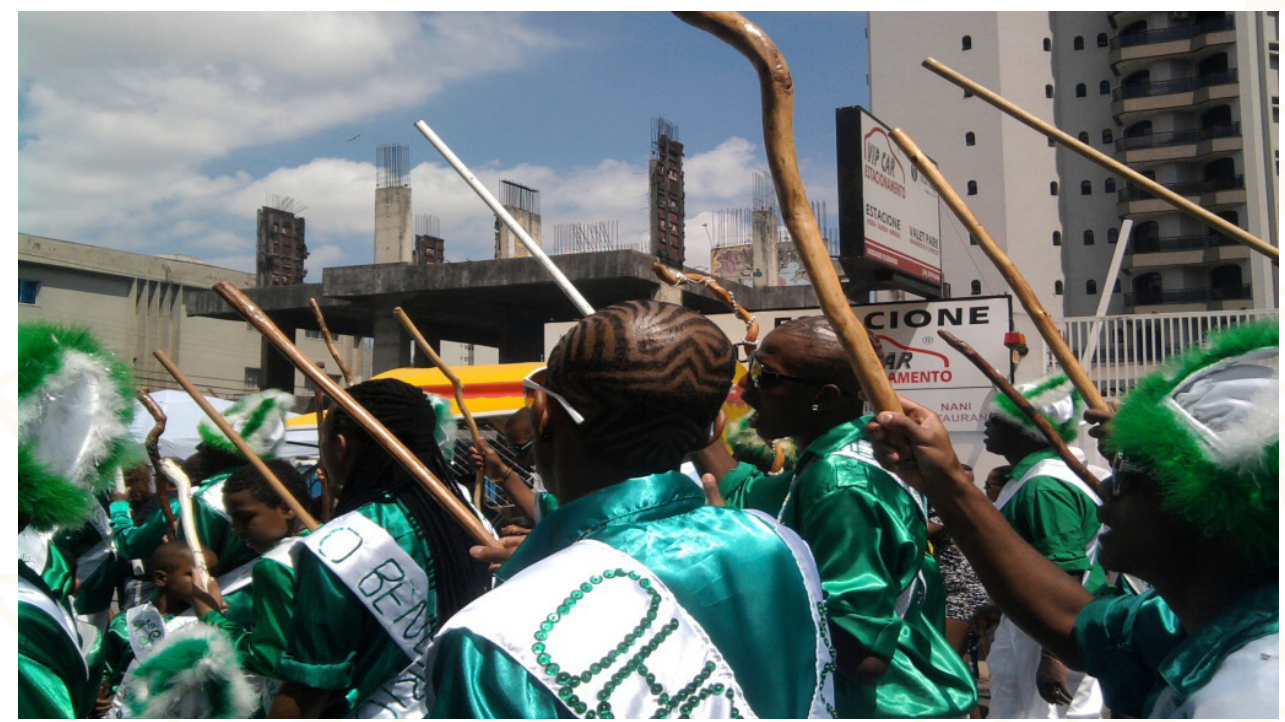

Figura 2 - Dançadores do Moçambique de Belém levantando seu bastão em canto quase às portas da igreja Nossa Senhora do Rosário, 2012. Imagem: Tatiane Oliveira.

A hierarquização observada, muitas vezes é um dos motivos de desentendimentos entre alguns ternos, apesar de sua causa comum. Além disso, há também as "disputas" de cunho religioso durante a festa. De fato, pudemos observar manifestações de receio de que os outros grupos pudessem sabotar um terno por meio de trabalhos espirituais. Durante o "Encontro de Moçambiques, Marinheiros, Marujos e Catupés", ouvimos de uma participante que os dançadores não pisam em bueiros nas ruas, pois se acredita que ternos inimigos possam colocar feitiços nos mesmos. Todo e qualquer vestígio que um terno deixa ao passar é considerado uma ameaça ao terno que o sucede na caminhada.

Outro destaque de contraste está no campo da musicalidade. Enquanto os demais ternos entoam seus cantos acompanhados pela percussão marcando um compasso binário simples, os ternos de Moçambique efetuam uma batida de um compasso binário composto. Essa constatação nos leva ao ponto de que, tanto nos ensaios como na festa, os congadeiros lidam, consciente ou inconscientemente, com uma questão bastante importante na música, a polirritmia, que nasce do emprego simultâneo de duas ou mais estruturas rítmicas diferentes em sua constituição. Os ternos saem de seus quartéis, cada um entoando os seus cantos de acordo com a sua contagem e, quando se 
encontram, tocam conjuntamente, mas cada um mantendo a sua pulsação, não se deixando contaminar nem pelo ritmo nem pelo canto do outro.

A polirritmia e a utilização dos objetos na dança auxiliam o brincante na composição de sua partitura corporal, movimento que chamaremos de performance cultural, que, na esteira de Richard Schechner (SCHECHNER, 2012a, p. 19) e da visão antropológica de Vitor Turner, pauta-se na relação com o ato performático extraído de um jogo ritualístico. Schechner resume a acepção com as seguintes palavras: "Performances são fazer-crer no jogo, por prazer", e mais adiante registra que as "performances são usualmente subjuntivas, liminares, perigosas e cercadas por convenções e molduras; são meios de fazerem os lugares, os participantes e os eventos de alguma maneira seguros" (loc. cit.). Logo, o primeiro aspecto abordado na entrevista de Schechner está relacionado ao comportamento do sujeito que, ao fazer parte de um jogo, seja ritual, teatral ou mesmo cotidiano, reitera por meio de seu corpo um enunciado, cuja memória aponta para um "modo subjuntivo, o propalado 'como se.' Portanto, de acordo com o autor, "a performance é uma ilusão da ilusão" e, como tal, deve ser considerada mais "cheia de verdade", mais "real que a experiência comum".

A reflexão de Schechner soma-se ao campo do ritual observado no início da pesquisa e o ilumina. Durante o período que antecede a primeira festa, que geralmente ocorre no mês de maio, alguns ternos, como o Moçambique Quilombo ${ }^{3}$, fazem campanhas, leilões e visitam igrejas, residências e centros como os de Candomblé, Umbanda e Omolokô4, locais de rituais de origem africana, uma vez que no período da festa se constata mais seu lado cristão, pois é realizada às portas da igreja católica.

Essas visitas são de extrema importância, já que se trata de uma festa religiosa caracterizada pelo ecletismo. Existem algumas divergências no que se refere à religiosidade do congado, pois, apesar de alguns se dizerem católicos, existem rituais de preparação que são específicos e indispensáveis e

3 A opção por observar um grupo diferente do citado anteriormente seu deu pelo fato de que o Moçambique de Belém não participar da festa realizada no período de maio. Devido à existência de duas Irmandades Congadeiras atuando simultaneamente na cidade em um determinado período da história. Essa divisão causa, ainda que secretamente, certa segregação no movimento, uma vez que os ternos que não participam da festa de outubro devido ao não cumprimento das normas necessárias a sua participação podem ser aceitos na festa de maio.

4 Religião de matriz africana. 
que não são pertencentes ao catolicismo, como o "fechamento do corpo" e a "defumação das caixas".

Há também outros elementos que comprovam que se trata de um movimento extremamente híbrido. A superstição ainda é bastante aguçada. Antes de sair às ruas, o terno faz a sua oração pedindo proteção a todos os integrantes do grupo, livrando-os de todo mal que possa acontecer durante o percurso, inclusive magias e feitiços que possam ter sido feitos. Sobre essa tradição africana e processo de aculturação entre as duas religiões, uma canção entoada por eles se destacou durante a observação realizada:

São Benedito, sua casa tá cheia

Mãe do Rosário é que nos clareia...

Hoje é dia de preto, vamos saravá...

Quando balanço a minha gunga, chamo meus ancestrais,

E eles incorporam nos pobres mortais...

Então firma daí, que eu firmo de cá...

Tá no chão, deixa aí. É feitiço... feitiço não pode pegar

Louve para o céu, olhe para o lado...

Então firma comigo na festa do congado...

Oh, meu pai do céu, proteja meus soldados

Oh, minha mãe do céu, proteja minha bandeira

Os meus pretos nunca foram de guerra...

Eles sempre buscaram a paz...

A magia do meu bastão contagia os demais...

A magia do meu bastão contagia os demais...

Louve para o céu, olhe o para o lado...

Então firma comigo na festa do congado...

Oh, meu pai do céu, proteja meus soldados...

Oh, minha mãe do céu, proteja minha bandeira.

(Canto entoado pelo Moçambique de Belém, 2012) 
Percebe-se nos versos que compõem a cantiga uma série de fatores, como a busca pela paz, a honra aos santos e aos ancestrais simultaneamente reforçando a religiosidade híbrida, entre outros. Pereira Queiróz (apud SILVA, 2010) faz referência ao hibridismo da religião, em especial a católica. Sustenta-se a ideia de que a religião católica fragmenta-se em sete tipos de catolicismo: oficial; cultural; popular; catolicismo misturado com magias e crenças indígenas; catolicismo associado aos cultos africanos; catolicismo reunido ao espiritismo; e catolicismo em sincretismo com o espiritismo e cultos africanos.

Portanto, as nossas observações in loco corroboram a divisão reapresentada por Pereira Queiróz e referendam a noção de "popular" já citada por Canclini, quando diz que "o popular é constituído de processos híbridos e complexos, usando como signos de identificação elementos procedentes de diversas classes e nações", e com Augusto Arantes, quando coloca que "a cultura popular é, na verdade, construída através da justaposição de elementos residuais e fragmentários considerados resistentes a um processo 'natural' de deterioração". Refletindo sobre a prática do congado, se a festa é uma manifestação às portas da Igreja católica e aos seus santos, ela é também, como no ritual de base africana que a precede e como mostra a canção, uma forma de resistência a um processo de deterioração da tradição. Ela apresenta um sincretismo religioso, com imagens das esferas católica e africana, mas com predomínio de elementos da tradição africana, a exemplo dos cultos aos antepassados e aos orixás. A festa é uma das maneiras encontradas para que se evite o esquecimento de experiências vividas durante o longo processo de escravidão, o qual pode ter levado ao sincretismo citado: memória de um tempo vivido na África, mais o tempo vivido no processo de doutrinação dos negros escravizados.

Nos ensaios que acompanhamos, o número de integrantes do terno era elevado e heterogêneo, dentre eles, idosos, adultos, jovens e crianças. Ainda nos primeiros leilões frequentados, foi possível observar aspectos modernos dessa festa tradicional. Para além da religiosidade, as pessoas ali presentes usufruíam do momento para ouvir música em seus carros com sons potentes, e os jovens se divertiam de maneira descontraída. O que nos volta à reflexão de como as novas influências não rompem com a tradição, e como os grupos se reorganizam na sociedade moderna em que vivemos e como tais elementos se inserem no universo do ritual tradicional. Atentamos para o fato de que a fes- 
ta também significa um momento de descontração, de encontro e celebração entre iguais que seguem juntos em sua arte de resistência, somado ao caráter religioso que está sempre presente. Para referendar a constatação de certas transformações ou movência cultural, convidamos a voz de Stuart Hall (2003) para iluminar esse contraste: 'A Cultura Popular não é, num sentido 'puro', nem as tradições populares de resistência a esses processos, nem as formas que as sobrepõem. É o terreno sobre o qual as transformações são operadas” (p. 132).

Portanto, não é legítimo pensar que um movimento permaneça imutável e impermeável às mudanças ocorridas ao longo do tempo. No entanto, deve-se questionar até onde a inserção de elementos contribui para uma ressignificação da tradição e até onde esta é positiva para o movimento. Nosso foco, embora permanente na movimentação dos congadeiros mais velhos, é permeado por uma observação da festa enquanto um evento de autoafirmação das raízes negras e festividade social. Aqueles que assumiam o congado enquanto compromisso religioso e de louvor, aos poucos vão cedendo lugar àqueles que podem se juntar ao movimento com outros interesses, para além de louvar os santos e se fazerem presentes devido à questão de pertencimento e inserção em um determinado grupo. Foi possível observar que, no seio da comunidade afro-uberlandense, aqueles que participam da festa do congado possuem um determinado status social e são reconhecidos dentro dos grupos.

Diante dessa constatação e observação da festa, notamos que o movimento vem sofrendo um processo de espetacularização, uma vez que o caráter estético e artístico da festa vem sendo levado mais em conta por parte de muitos jovens, que acabam sempre por serem os defensores e mantenedores da tradição ao longo dos séculos.

Sabemos que o congado de hoje pouco se assemelha ao ritual de 80 anos atrás. Houve a inserção de novos instrumentos, mudança no modelo das roupas, que passou a variar de ano em ano, assim como a forma e a língua em que os cantos são entoados e o material de confecção de instrumentos e indumentárias, entre outros. Sobre essas mudanças, apoiamo-nos na fala de Antônio Augusto Arantes (1980):

Procurando-se "reproduzir" objetos e práticas supostamente cristalizados no tempo e no espaço, acaba-se por "produzir" versões modificadas, 
no mais das vezes esquemáticas, estereotipadas e, sobretudo, inverossímeis (aos olhos dos produtores originais) dos eventos culturais com os quais se pretende constituir o patrimônio de todos. Embora se procure ser fiel à "tradição", ao "passado", é impossível deixar de agregar novos significados e conotações ao que se tenta reconstituir. Isso é inevitável, porque a própria reconstituição é informada por e é parte de uma reflexão sobre a história da cultura e da arte que, em grande medida, escapa aos produtores "populares" da cultura. (p. 19)

Essa tendência voltada para o aspecto visual se tornou mais presente, de fato, a partir dos anos 2000, em Uberlândia, uma cidade que se caracteriza por sua forte marca percussiva e conta com a soma de elementos de grande modificação nas simbologias festivas. Os ternos passam a desfilar com indumentárias mais modernas e há a inserção de novas imagens nos estandartes, onde inicialmente só eram permitidas as imagens dos santos, etc.

J. Brasileiro (2013) relatou eventos em que jovens capitães o procuravam para saber como realizar determinados rituais característicos, os quais já deviam ser dominados anteriormente ao processo de criação do terno. De qualquer maneira, vemos que tal comportamento, ainda que diferente, é uma forma de manutenção das tradições, e que os brincantes procuram movimentos que possam ser restaurados, no dizer de Schechner (2012b): "o comportamento restaurado é usado em todos os tipos de performance: do xamanismo e do exercício do transe, do ritual à dança estética" (p. 244). Mesmo com grandes mutações, o congado, para esses jovens, constitui-se como uma forma de contato com leituras sobre suas identidades e contribui para a manutenção de uma tradição que ao mesmo tempo se converte na criação de um novo movimento, dada a reconfiguração a que ele é submetido.

Aos poucos, o corpo vai se transformando em instrumento da imagem e a movimentação deixa de ter uma significação de referência ancestral e passa a ser vista por alguns como um passo de dança a ser apreendido, não mais tão dotado de força religiosa. Torna-se, pois, um novo movimento também dotado de força e energia, embora os motivos possam não ser mais os mesmos. Mas, por um caminho ou outro, o comportamento restaurado vem à baila - com maior ou menor força - quando o brincante se propõe a entrar no ritual, embora o corpo, antes dançante, acabe se tornando um "depósito" cada 
vez maior de aparatos, como colares, brincos, tranças e apliques de modelos e cores diferentes no cabelo, realizados especialmente para o dia da festa.

Desde o início dos ensaios, um clima diferente se estabelece na cidade, principalmente dentro da irmandade congadeira. Toda noite é possível ouvir o som de algum grupo ensaiando, fazendo suas campanhas de casa em casa. Essas campanhas são visitas feitas a pessoas que abrem suas casas para a entrada do terno de congado; antigamente, entrava-se em todas as casas que estivessem com suas portas abertas e que os donos autorizassem a visita. Acreditamos que, devido a isso e à ignorância e preconceito de muitos, por muito tempo se alimentou o medo do congado. Medo revivido, do negro e suas manifestações religiosas. Sempre que se ouvia a batida, pais recolhiam seus filhos e fechavam as portas de suas casas, acreditando que o congado tratava-se de um ritual maligno. Para não passar por essa situação, atualmente, as casas são previamente selecionadas e cada terno faz um mapa das residências que irão visitar ao longo do período de ensaios. Esse clima de festividade se estende até depois da festa, o que, para nós, ainda confere a ela um caráter mágico ${ }^{5}$.

Ao longo das observações e entrevistas, as pessoas que participam da congada dizem que se trata de uma prática para a vida toda, que vai além do período da festa. Mas, não conseguimos identificar manifestações nesse seguimento fora dos períodos que antecedem as festas de maio e agosto, o que confere à prática um caráter mais festivo e efêmero, não retirando o mérito da tradição, se seguimos uma das coordenadas de Bakhtin.

Em entrevista, perguntamos a Ramon Rodrigues, capitão do Moçambique de Belém, a respeito da intensidade do movimento em momentos fixos do ano e sua ausência fora do período da festa, apesar de dizerem que a prática é para a vida toda. Talvez possamos entender essa afirmativa com a intenção de dizer que quem é congadeiro participa da festa todos os anos, mantendo ao longo do tempo a sua postura de representante dessa cultura e lutando para

5 Para essa trajetória festiva, destacamos uma fala de Bakhtin (1999) quando diz da necessidade de expressão pelo homem de sua concepção de mundo: "As festividades (qualquer que seja seu tipo) são uma forma primordial, marcante, da civilização humana. Não é preciso considerá-las nem explicá-las como um produto das condições e finalidades práticas do trabalho coletivo nem, interpretação mais vulgar ainda, da necessidade biológica (fisiológica) de descanso periódico. As festividades tiveram sempre um conteúdo essencial, um sentido profundo, exprimiram sempre uma concepção de mundo" (p. 7). 
que ela seja mantida e preservada. O capitão confirmou sua preocupação com esse aspecto e nos informou que essa é uma de suas lutas: fazer com que os grupos se façam presentes em outros períodos e não somente nos da festa.

Outro caráter social importante é o da participação das mulheres que, com o passar dos anos, vêm ocupando cada vez mais espaço na prática. Antes Ihes era permitido participar somente carregando a bandeira do terno, atualmente existem mulheres que tocam instrumentos (patangoma e caixa). Há outros ternos, como o Moçambique Branco da cidade de Araguari, onde muIheres usam gungas, o que antes era permitido somente aos homens. Mais um aspecto que concretiza a mudança de hierarquia no universo festivo em foco.

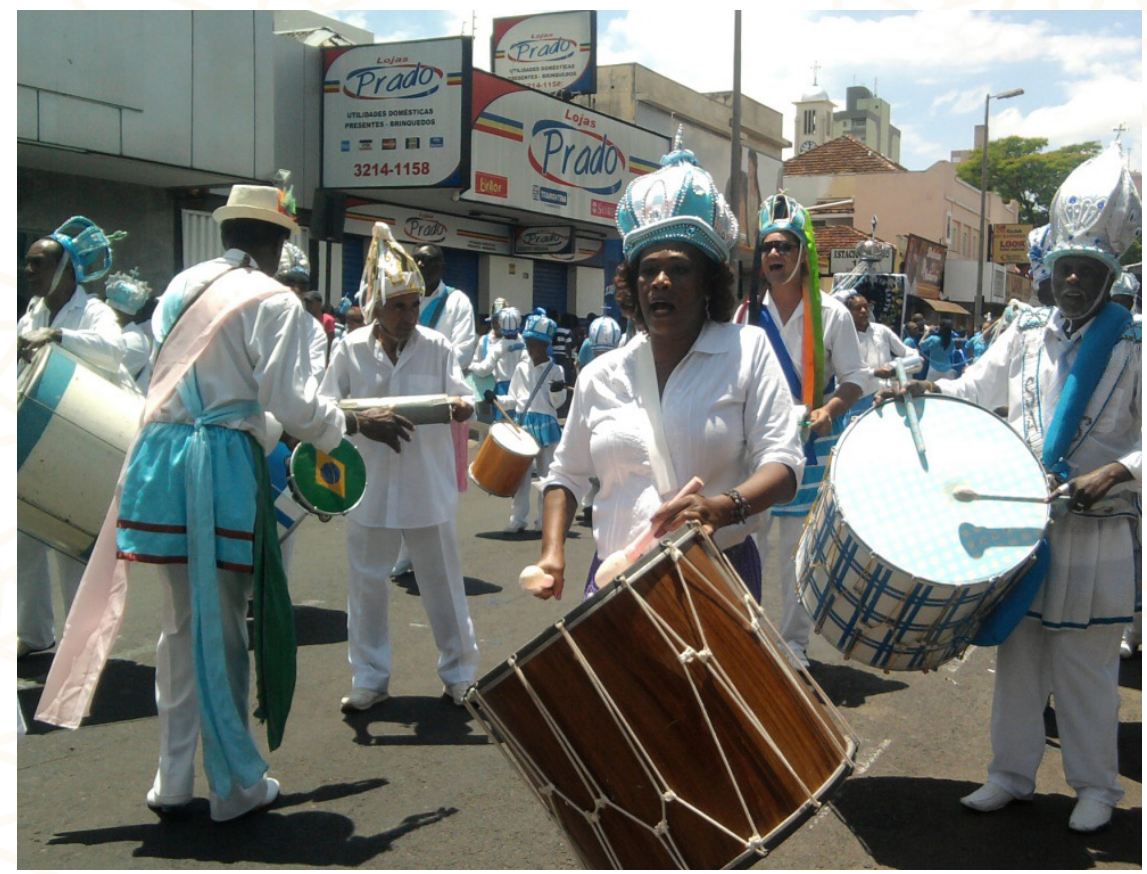

Figura 3 - Integrante do tradicional Terno Sainha de Uberlândia tocando caixa, 2012. Imagem: Tatiane Oliveira.

Mesmo com toda essa transformação da festa, dos costumes anunciados anteriormente, não há apagamento do ritmo, somado ao culto da religiosidade, quanto à expressão corporal. A linguagem do corpo que se apresenta de forma encurvada, os joelhos flexionados, a batida dos pés, o balançar dos ombros, o olhar imponente e a oscilação rítmica do quadril são movimentos típicos do moçambiqueiro enquanto realiza e busca energia para efetivar a dança. Além de um movimento coreografado, tais passos são uma referên- 
cia aos pretos velhos, os guerreiros ancestrais, repassados, reconstruídos e ressignificados ao longo dos anos. Com eles, a necessidade a que se refere Bakhtin (1999) de se mostrar um sentido mais profundo, mais essencial, é ainda muito viva.

O dançador é antes de tudo um militante, um indivíduo que manifesta, através de seu corpo, a reverência, a honra, a guerra e a vitória. Isso faz do congado, além de tudo, um movimento de afirmação do negro na sociedade, uma prova viva das lutas vencidas no passado e no presente. Não é somente uma referência ao sofrimento do negro no tempo de escravidão, mas é, também, como um feixe de luz, por meio da manutenção do tradicional, do sagrado, da festa, o momento que faz de todos iguais e instaura um clima de unificação.

O ritmo fortemente marcado pelo bater das caixas, do sacolejo das patangomas e do chacoalhar das gungas faz com que dançar e tocar se converta em uma única movimentação, não podendo discernir o que vem do corpo ou da voz. Pela voz, o canto também eleva o movimento do corpo, uma vez que as palavras e os louvores dançam no ar e entranham-se como linguagem corporal. A dança e o canto são elementos presentes na maioria das religiões e alcançam dimensões imperceptíveis no campo do racional e do sensorial.

Nesse aspecto, especialmente, longe dos espaços comuns destinados a apresentações teatrais, inclusive as recentes arenas, as performances se constituem como um meio de criação de espaços. A congada, por mais espetacularizada, modificada, ressignificada e mutável que seja, não deixará de ser uma festa que reconta a história por meio do canto, da dança e da religião, criando assim seus próprios espaços. É sempre a rememoração de fatos históricos e matrizes religiosas de mais de trezentos anos que, juntos, reconstroem um lugar, donde vazam histórias de lutas antigas e cotidianas de um povo. É a reinvenção da tradição de uma sociedade, através de uma linguagem corpóreo-vocal, antropológica e religiosa.

\section{Referências bibliográficas}

ARANTES, A. A. O que é cultura popular. 14. ed. São Paulo: Brasiliense, 1980.

BAKHTIN, M. A cultura popular na Idade Média e no Renascimento: o contexto de François Rabelais. São Paulo: Hucitec; Brasília: UnB, 1999. 
BRASILEIRO, J. Congadas de Minas Gerais. Brasília, DF: Fundação Cultural Palmares, 2001.

Jeremias Brasileiro: depoimento. Entrevistadora: Tatiane Oliveira Silva. [Uberlândia]: fev. 2013. Entrevista concedida para a pesquisa Pibic/Fape$\mathrm{mig} / 2012 / 2013$.

CANCLINI, N. G. A encenação do popular. In: Culturas híbridas: estratégias para entrar e sair da modernidade. 3. ed. São Paulo: Edusp, 2000. p. 205-264. $H A L L$, S. Cultura popular e identidade. In: Da diáspora, identidades e mediações culturais. Belo Horizonte: UFMG; Brasília, DF: Unesco, 2003. p. 231-330. HOBSBAWM, E.; RANGER, T. Introdução. In: A invenção das tradições. São Paulo: Paz e Terra, 2006. p. 9-23.

RODRIGUES, R. Ramon Rodrigues: depoimento. Entrevistadora: Tatiane Oliveira Silva. [Uberlândia]: dez. 2012. Entrevista concedida para a pesquisa Pibic/Fapemig/2012/2013.

SCHECHNER, R. Entrevista concedida a Zeca Ligiéro. In: LIGIÉRO, Z. Performance e antropologia de Richard Schechner. Rio de Janeiro: MauadX, 2012a.

Restauração do comportamento. In: BARBA, E.; SAVARESE, N. A arte secreta do ator: um dicionário de antropologia teatral. Tradução Patricia Furtado de Mendonça. São Paulo: É realizações, 2012b.

SEKITO, L. Corpo e Identidade: algumas considerações a partir de um processo de criação em dança. Revista Ensaio Geral, Belém, v. 3, n. 3, p. 71-82, 2010.

SILVA, M. C. G. Vozes do cerrado: performance, memorial e ritual: reconstruindo a identidade dos foliões de João Pinheiro, Minas Gerais. In: TEIXEIRA, J. G. L. C.; VIANNA, L. C. R (Orgs.). As artes populares no Planalto Central: performance e identidade. Brasília, DF: Verbis, 2010.

VLADIMIR, F. Fábio Vladimir: depoimento. Entrevistadora: Tatiane Oliveira Silva. [Uberlândia]: ago. 2012. Entrevista concedida para a pesquisa Pibic/Fape$\mathrm{mig} / 2012 / 2013$.

Recebido em 20/04/2016

Aprovado em 17/05/2016

Publicado em 01/07/2016 